Tạp chí Khoa học và Công nghệ biển T12 (2012). Số 2. Tr 77 - 87

\title{
TÁC DỤNG CỦA RÙ̀ NG NGẬP MẬN ĐẾN BỒI TỤ NỀN ĐÁY Ở VÙNG VEN BỜ BÀNG LA (ĐỒ SƠN, HẢI PHÒNG)
}

\section{VŨ ĐOÀN THÁI}

\section{Đại học Hải Phòng}

\begin{abstract}
Tóm tắt: Các kết quả nghiên cứu về rù̀ng ngập mặn (RNM) gần đây đều chỉ ra rằng: sư mở rộng diện tích đất bồi và sư phát triển của RNM là hai quá trình luôn đi kèm nhau. Trong bài báo này, chúng tôi chứng minh rõ nhận định trên bằng việc nghiên cúu khu vực xã Bàng La (Đồ Son, Hải Phòng) về vai trò giảm sóng của RNM làm tăng cuờng bồi tu nền đáy tỷ lệ. Vai trò này tăng dần cùng với độ tuổi của rù̀ng trong thời gian nghiên cưu.
\end{abstract}

\section{MỞ ĐÀ̀U}

Các kết quả nghiên cứu gần đây về diễn biến xói lở - bồi tụ ven bờ biển Hải Phòng đã cho thấy đặc điểm xói lở - bồi tụ ở Hải Phòng có 4 hình thái cơ bản [7]. Tại khu vực ở xã Bàng La (Đồ Sơn) và Đại Hợp (Kiến Thụy), diễn biến bồi - xói thuộc hình thái xói lở đã nhiều năm và gần đây chuyển sang bồi tụ.

Qua thực tế nghiên cứu tại khu vực này, chúng tôi nhận thấy quá trình bồi tụ diễn ra ngày một tăng lên qua các năm gần đây cùng với sự suy giảm chiều cao sóng tác động vào bờ. Bài báo này trình bày kết quả khảo sát và đánh giá tác dụng của khu RNM chắn sóng và làm tăng độ bồi tụ nền đáy tại khu vực xã Bàng La (Đồ Sơn, Hải Phòng).

\section{TÀI LIỆU VÀ PHƯƠNG PHÁP NGHIÊN CÚU}

\section{Tài liệu}

Tài liệu sử dụng trong nghiên cứu này bao gồm các số liệu đo cấu trúc RNM tại xã Bàng La - Đồ Sơn và độ cao nền đáy từ năm 2004 đến 2012. Ngoài ra, bài viết các tài liệu khác có liên quan đến điều kiện sinh thái RNM và động lực bờ của các tác giả trong và ngoài nước.

\section{Phương pháp}

Để nghiên cứu cấu trúc RNM, kiểu rừng trồng chịu được tác động của sóng, bão và giảm thiểu độ cao sóng, áp lực sóng trước khi tác động vào bờ, các phương pháp sau đây đã được tiến hành [6]. 


\section{Nghiên cúu và phân loại các kiểu cấu trúc RNM:}

Đo kích thước và số lượng cây RNM dựa theo các phương pháp của Braun Blanquet [3], S.Aksornkoe [1]. Các ô nghiên cứu được bố trí dọc theo mặt cắt vuông góc với đê biển tính từ mép rừng sát đê ra phía biển. Ngoài ra, còn khảo sát theo chiều song song với bờ tại một số điểm tùy theo địa hình và phân bố của cây ngập mặn. Rừng trang (Kandelia obovata Shuen, Lui and Yong) được đo mỗi ô có kích thước $10 \mathrm{~m}$ x 10m. Rừng bần chua (Sonneratia caseolaris (L.) Engl.) được đo mỗi ô có kích thước $25 \mathrm{~m} \times 60 \mathrm{~m}$ (Phan Nguyên Hồng, Hoàng Thị Sản) [4].

Xác định độ che phủ của tán lá rùng theo công thức:

$$
\mathbf{L}=\frac{S}{G}
$$

Trong đó: L: Độ che phủ của tán lá rừng; $\mathrm{S}$ : Diện tích đất được che phủ tính theo $\mathrm{m}^{2}$,

G: Diện tích nền đất.

Quan trắc sóng:

Từ năm 2005 đến 2010 quan trắc sóng bằng máy đo sóng tự ghi $\mathrm{DNW}-5 \mathrm{M}$ và máy ngắm sóng IVANOP-H10 kết hợp với cột thủy chuẩn (MIA) đặt tại điểm cách bờ $2 \mathrm{~m}$.

Hệ số suy giảm độ cao sóng khi qua RNM được tính theo công thức của Mazda (1997) [5]:

$$
R=\frac{H_{S}-H_{L}}{H_{S}}
$$

\section{Trong đó:}

R: Hệ số suy giảm độ cao sóng; $\mathrm{H}_{\mathrm{s}}$ : Độ cao của sóng trước rừng (điểm thả phao hoặc máy) cách mép rừng phía ngoài biển $100 \mathrm{~m} ; \mathrm{H}_{\mathrm{L}}$ : Độ cao của sóng tại điểm gần sát bờ.

Đo độ cao nền đáy:

Độ cao nền đáy được so với mực chuẩn số "0 độ sâu" - trùng với mực nước ròng thấp nhất (Tiêu chuẩn ngành, 1991) [8].

Độ cao nền đáy: $H=H_{1}-h$

\section{Trong đó:}

$\mathrm{H}$ : Độ cao nền đáy; $\mathrm{H}_{1}$ : Độ sâu cột nước tại thời điểm đo; h: Giá trị mực nước tại thời điểm đo trong bảng thủy triều [2].

Dùng máy đo sâu hồi âm Hondex Ps-7 đo sâu tại các vị trí có cọc đánh dấu xác định mức độ bồi tụ đất kết hợp với phương pháp trên để nâng cao độ chính xác của kết quả đo. 


\section{Đánh giá tốc độ bồi tu nền đáy RNM:}

Dùng cọc tre dài $1,3 \mathrm{~m}-1,8 \mathrm{~m}$ đóng chặt xuống nền đáy dọc theo tuyến nghiên cứu từ phía đê ra biển với khoảng cách $100 \mathrm{~m} / \mathrm{cọc}$ trên cả 3 ô nghiên cứu theo mặt cắt ngang từ bờ ra ngoài mép rừng. Tổng số cọc cắm là 24 cọc. Đánh dấu các khoảng cách vào cọc ở vị trí cách mặt bãi triều $20 \mathrm{~cm}$. Ghi lại giá trị ban đầu và giá trị nhận được sau 6 tháng để tính lượng bồi lắng. Các đo đạc được tiến hành 2 lần/năm vào mùa khô và mùa mưa, trong thời gian từ năm 2004 đến đầu năm 2012.

\section{KẾT QUẢ VÀ THẢO LUẬN}

\section{Kết quả khảo sát cấu trúc của rù̀ng ngập mặn ở khu vực nghiên cứu}

\subsection{Thành phần loài và sụ phân tầng cây trong rùng}

Từ năm 2004 đến 2006: $350 \mathrm{~m}$ rừng từ mép nước vào phía đê biển chỉ có thuần là trang. Trên sàn rừng có rất ít các loài cây khác, cây tái sinh với mật độ rất thưa, khoảng 6 -30 cây $/ \mathrm{m}^{2}$.

Từ năm 2007 đến 2008: 350m rừng này cũng chỉ có thuần loài trang, số lượng cây tái sinh trên sàn rừng với mật độ $6-25$ cây $/ \mathrm{m}^{2}$; độ cao cây $40-50 \mathrm{~cm}$.

Từ năm 2009 đến $2011: 350 \mathrm{~m}$ rừng này cũng vẫn chỉ thuần loài trang, trên sàn rừng cây tái sinh với mật độ $6-20$ cây $/ \mathrm{m}^{2}$; độ cao cây $45-55 \mathrm{~cm}$.

Tuy nhiên, từ năm 2010, được sự chỉ đạo của thành phố, địa phương đã trồng rừng lấn thêm ra phía biển. Tại đây trồng bần chua thuần loài ra phía rìa ngoài (ngoài rừng trang). Hiện nay, cây cao đồng đều, tỷ lệ sống đạt $55-60 \%$, độ rộng dải rừng là $200 \mathrm{~m}$.

Nửa phía trong gần bờ có bần chua trồng xen với rừng trang với mật độ rất thưa.

Dải bãi gần sát chân đê rộng khoảng $50 \mathrm{~m}$, trước đây là phần để trống không trồng cây, mục đích làm chỗ neo đậu thuyền chài lưới của bà con vào trú sóng gió. Tại đây, khi mực nước triều ở khoảng $2,7-2,8 \mathrm{~m}$ so với mực nước triều thấp nhất, thuyền chài lưới nhỏ của ngư dân vẫn ra vào dễ dàng. Từ năm 2008 đến nay, cây con tái sinh trôi dạt vào, mọc dày đặc, sinh trưởng, phát triển rất nhanh, thuần loài trang.

Từ số liệu chiều cao cây, có thể chia quần xã RNM khu vực này thành các tầng cây sau:

Tầng 1: tầng cây cao vượt tán: bần chua (Sonneratia caseolaris (L.) Engl.), (ảnh 1).

Tầng 2: tầng cây khép tán: trang (Kandelia obovata Shuen, Lui and Yong), (ảnh 1).

Tầng 3: tầng cây tái sinh: trang (Kandelia obovata Shuen, Lui and Yong). 


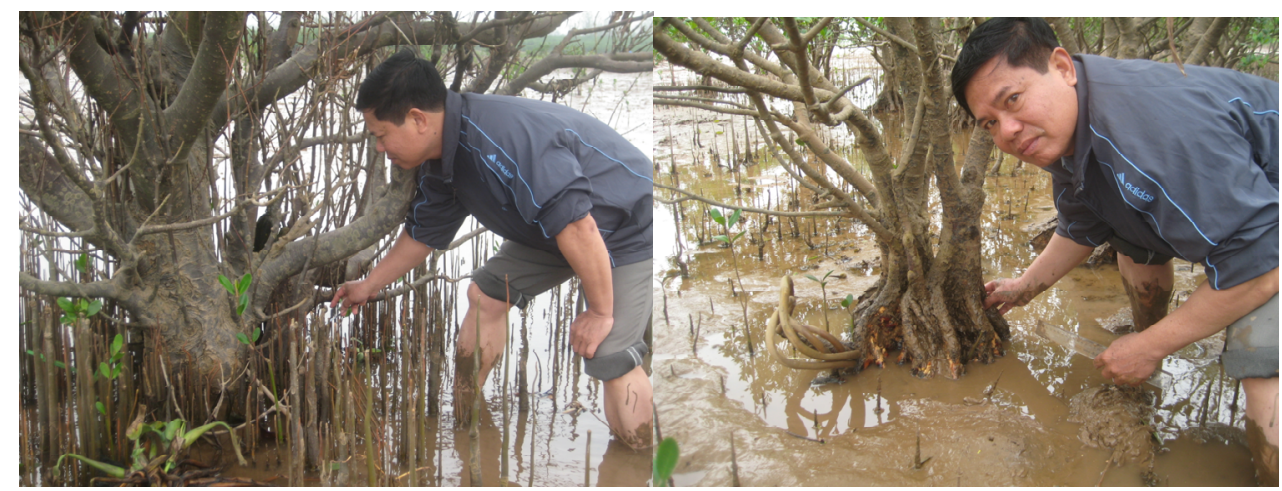

A

C

Ảnh 1: Cây bần chua (Sonneratia caseolaris (L.) Engl.) (A)

và cây trang (Kandelia obovata Shuen, Lui and Yong) (B) cách rìa ngoài rừng $400 \mathrm{~m}$

\subsection{Mật độ, số luộng, kích thước cây rùng}

Rừng có độ rộng $900 \mathrm{~m}$ này được phân ra như sau: dải rừng có độ tuổi 13,5 - 14,5 rộng $650 \mathrm{~m}$; dải rừng bần chua mới trồng được 1,5 năm tuổi (tháng 8 năm 2010) ở ngoài mép nước rộng $200 \mathrm{~m}$; dải rừng tái sinh sát chân đê rộng $50 \mathrm{~m}$ đã được 4,5 năm tuổi. Về mặt cấu trúc quần xã thực vật, đây là quần xã hỗn hợp nhưng được tách thành từng phần, sự hòa trộn không lớn lắm. Chiều cao, đường kính thân lớn nhất là loài bần chua. Chúng được trồng cùng năm với cây trang nhưng lại vượt hẳn về kích thước do đặc điểm của loài trong quá trình sinh trưởng, phát triển (bảng 1 ).

Bảng 1: Số lượng, kích thước các cây trong ô tiêu chuẩn ở RNM tại xã Bàng La

\begin{tabular}{|c|c|c|c|c|c|c|}
\hline \multirow[b]{2}{*}{ Năm } & \multirow[b]{2}{*}{$\begin{array}{c}\text { Độ tuổi \& } \\
\text { Tổng số theo nhóm }\end{array}$} & \multicolumn{5}{|c|}{ Các chỉ tiêu } \\
\hline & & $\begin{array}{c}\text { Số } \\
\text { lượng } \\
\text { cây/ha }\end{array}$ & $\begin{array}{l}\text { Đường } \\
\text { kính } \\
\text { thân lớn } \\
\text { nhất } \\
\text { (mm) }\end{array}$ & $\begin{array}{c}\text { Đường } \\
\text { kính } \\
\text { thân } \\
\text { trung } \\
\text { bình } \\
\text { (mm) }\end{array}$ & $\begin{array}{l}\text { Chiều } \\
\text { cao thân } \\
\text { lớn nhất } \\
(\mathrm{cm})\end{array}$ & $\begin{array}{c}\text { Chiều } \\
\text { cao } \\
\text { thân } \\
\text { trung } \\
\text { bình } \\
(\mathrm{cm})\end{array}$ \\
\hline \multirow{5}{*}{2004} & Bần 5 tuổi & 400 & 150 & 121 & 420 & 380 \\
\hline & Trang 5 tuổi & 17.500 & 91 & 76 & 190 & 172 \\
\hline & Tổng số & 17.900 & & & & \\
\hline & Trang 6 tuối & 18.200 & 110 & 86 & 205 & 195 \\
\hline & Tổng số & 18.200 & & & & \\
\hline 2006 & Bần 7 tuổi & 400 & 182 & 154 & 545 & 510 \\
\hline
\end{tabular}




\begin{tabular}{|c|c|c|c|c|c|c|}
\hline & Trang 7 tuổi & 17.500 & 123 & 108 & 232 & 214 \\
\hline & Tổng số & 17.900 & & & & \\
\hline & Trang 8 tuổi & 18.200 & 130 & 118 & 247 & 238 \\
\hline & Tổng số & 18.200 & & & & \\
\hline \multirow{6}{*}{2008} & Bần 9 tuổi & 393 & 212 & 184 & 640 & 620 \\
\hline & Trang 9 tuổi & 17.400 & 153 & 135 & 274 & 256 \\
\hline & Tổng số & 17.793 & & & & \\
\hline & Trang 10 tuổi & 18.200 & 156 & 140 & 289 & 280 \\
\hline & Tổng số & 18.200 & & & & \\
\hline & $\begin{array}{l}\text { Trang tái sinh sát đê, } 1 \\
\text { tuổi }\end{array}$ & 68.000 & 12 & 10 & 120 & 100 \\
\hline \multirow{6}{*}{2010} & Bần 11 tuổi & 393 & 240 & 212 & 720 & 690 \\
\hline & Trang 11 tuối & 17.400 & 173 & 152 & 316 & 299 \\
\hline & Tổng số & 17.793 & & & & \\
\hline & Trang 12 tuổi & 18.200 & 180 & 158 & 329 & 319 \\
\hline & Tổng số & 18.200 & & & & \\
\hline & $\begin{array}{l}\text { Trang tái sinh sát đê, } 3 \\
\text { tuổi }\end{array}$ & 68.000 & 20 & 17 & 300 & 280 \\
\hline \multirow{7}{*}{2012} & Bần 12,5 tuổi & 393 & 255 & 231 & 760 & 740 \\
\hline & Trang 12,5 tuổi & 17.400 & 180 & 158 & 343 & 326 \\
\hline & Tổng số & 17.793 & & & & \\
\hline & Trang 13,5 tuổi & 18.200 & 185 & 161 & 362 & 358 \\
\hline & Tổng số & 18.200 & & & & \\
\hline & Bần mép nước 2 tuồi & 812 & 30 & 27 & 130 & 120 \\
\hline & $\begin{array}{l}\text { Trang tái sinh sát đê } 4,5 \\
\text { tuổi }\end{array}$ & 58.000 & 28 & 20 & 400 & 370 \\
\hline
\end{tabular}

Xét về toàn cục, tại khu vực xã Bàng $\mathrm{La}$, quần thể cây trang vẫn chiếm ưu thế vì rừng bần $200 \mathrm{~m}$ còn nhỏ, khả năng cản sóng không đáng kể.

Sát chân đê, tầng cây tái sinh chủ yếu là cây trang. Do mật độ quá dày (58.000 cây/ha) nên chỉ trong vòng 4,5 năm, cây đã đạt độ cao $3,7-4,0 \mathrm{~m}$, mặc dù thân rất mảnh $(2,0-2,8 \mathrm{~cm})$ nhưng vẫn tạo ra một bức tường cản sóng bảo vệ đê.

\section{Tác động giảm độ cao sóng của rùng ngập mặn}

Bờ biển ở khu vực xã Bàng La là nơi thường xuyên chịu tác động của sóng hướng Đông Nam. Việc đo sóng tại khu vực đã được tiến hành từ năm 2004, 2005, 2008 và 2011. 
Độ cao nền đáy ở khu vực tại chân đê là 2,4 - 2,5m, cách xa chân đê $850 \mathrm{~m}$ về phía biển là $1,9-1,8 \mathrm{~m}$.

Bảng 2: Độ cao và hệ số suy giảm độ cao sóng tại bãi có dải rừng rộng $650 \mathrm{~m}$ tại Bàng La - sóng hướng Đông-Nam (28/08/2004)

\begin{tabular}{|l|c|c|c|c|c|c|c|c|c|c|c|c|c|}
\hline & \multicolumn{9}{|c|}{ Độ cao sóng $(\mathbf{m})$} & \multicolumn{5}{c|}{ Hệ số suy giảm (\%) } \\
\cline { 2 - 13 } $\begin{array}{c}\text { Thòi } \\
\text { gian } \\
\text { (giò̀) }\end{array}$ & $\begin{array}{c}\text { Trước } \\
\text { rừng }\end{array}$ & $\begin{array}{c}\text { vào } \\
\text { rừng } \\
150 \mathrm{~m}\end{array}$ & $\begin{array}{c}\text { vào } \\
\text { rừng } \\
250 \mathrm{~m}\end{array}$ & $\begin{array}{c}\text { vào } \\
\text { rừng } \\
350 \\
\mathrm{~m}\end{array}$ & $\begin{array}{c}\text { vào } \\
\text { rừng } \\
450 \mathrm{~m}\end{array}$ & $\begin{array}{c}\text { vào } \\
\text { rừng } \\
550 \mathrm{~m}\end{array}$ & $\begin{array}{c}\text { sau } \\
\text { rừng }\end{array}$ & $\begin{array}{c}\text { vào } \\
\text { rừng } \\
150 \mathrm{~m}\end{array}$ & $\begin{array}{c}\text { vào } \\
\text { rừng } \\
250 \mathrm{~m}\end{array}$ & $\begin{array}{c}\text { vào } \\
\text { rừng } \\
350 \mathrm{~m}\end{array}$ & $\begin{array}{c}\text { Vào } \\
\text { rừng } \\
450 \mathrm{~m}\end{array}$ & $\begin{array}{c}\text { vào } \\
\text { rừng } \\
550 \mathrm{~m}\end{array}$ & $\begin{array}{c}\text { sau } \\
\text { rừng }\end{array}$ \\
\hline $14: 00$ & 0,4 & 0,16 & 0,09 & 0,06 & 0,05 & 0,04 & 0,02 & 60 & 78 & 85 & 88 & 90 & 95 \\
\hline $14: 15$ & 0,45 & 0,2 & 0,1 & 0,07 & 0,04 & 0,04 & 0,01 & 56 & 78 & 84 & 91 & 91 & 98 \\
\hline $14: 30$ & 0,45 & 0,2 & 0,1 & 0,06 & 0,04 & 0,03 & 0,03 & 56 & 78 & 87 & 91 & 93 & 93 \\
\hline $14: 45$ & 0,49 & 0,22 & 0,12 & 0,09 & 0,03 & 0,03 & 0,03 & 55 & 76 & 82 & 94 & 94 & 94 \\
\hline $15: 00$ & 0,56 & 0,25 & 0,14 & 0,08 & 0,05 & 0,05 & 0,02 & 55 & 75 & 86 & 91 & 91 & 96 \\
\hline $15: 15$ & 0,56 & 0,28 & 0,15 & 0,1 & 0,05 & 0,04 & 0,02 & 50 & 73 & 82 & 91 & 93 & 96 \\
\hline $15: 30$ & 0,49 & 0,23 & 0,11 & 0,08 & 0,04 & 0,04 & 0,03 & 53 & 78 & 84 & 92 & 92 & 94 \\
\hline $15: 45$ & 0,49 & 0,24 & 0,13 & 0,07 & 0,06 & 0,05 & 0,03 & 51 & 73 & 86 & 88 & 90 & 94 \\
\hline $16: 00$ & 0,45 & 0,21 & 0,1 & 0,06 & 0,05 & 0,05 & 0,02 & 53 & 78 & 87 & 89 & 89 & 96 \\
\hline $\begin{array}{l}\text { Trung } \\
\text { bình }\end{array}$ & 0,48 & 0,22 & 0,12 & 0,07 & 0,05 & 0,04 & 0,02 & 54 & 76 & 85 & 90 & 91 & 95 \\
\hline
\end{tabular}

Trong những ngày nước cường tháng 8 năm 2004 đã tiến hành đo chiều cao sóng bằng các phương pháp nêu trên tại khu vực rừng trang, bần xen trang có độ rộng $650 \mathrm{~m}$ và đã thu được kết quả trình bày trên bảng 2 .

Chiều cao sóng lớn nhất đo được vào lúc $15 \mathrm{~h}$ và $15 \mathrm{~h} 15$ là $0,56 \mathrm{~m}$ phía trước rừng $150 \mathrm{~m}$. Khi truyền vào rừng với khoảng cách $150 \mathrm{~m}, 250 \mathrm{~m}, 350 \mathrm{~m}, 450 \mathrm{~m}$ và $550 \mathrm{~m}$ độ cao sóng lần lượt còn lại là $0,25 \mathrm{~m} ; 0,14 \mathrm{~m} ; 0,08 \mathrm{~m} ; 0,05 \mathrm{~m}$ và tại rừng sát đê chỉ còn $0,02 \mathrm{~m}$.

Biến đổi độ cao và hệ số suy giảm độ cao sóng cho thấy độ cao sóng giảm mạnh khi qua $350 \mathrm{~m}$ rừng đầu tiên, tới $85 \%$ độ cao sóng (bảng 3 ). Sau đó, càng vào sâu trong $\mathrm{RNM}$ độ cao sóng tiếp tục giảm xuống, hệ số suy giảm độ cao sóng trung bình sau rừng trang tại xã Bàng La trong đợt khảo sát ngày 28/08/2004 là 95\%. 
Bảng 3: Độ cao và hệ số suy giảm độ cao sóng tại bãi có dải rừng rộng $700 \mathrm{~m}$ tại Bàng La - sóng hướng Đông Nam (27/08/2008)

\begin{tabular}{|l|c|c|c|c|c|c|c|c|c|}
\hline \multirow{2}{*}{$\begin{array}{c}\text { Thời } \\
\text { gian }\end{array}$} & \multicolumn{4}{|c|}{ Độ cao sóng $(\mathbf{m})$} & \multicolumn{3}{c|}{ Hệ số suy giảm (\%) } \\
\cline { 2 - 10 } & $\begin{array}{c}\text { Trước } \\
\text { rừng }\end{array}$ & $\begin{array}{c}\text { vào } \\
\text { rừng } \\
150 \mathrm{~m}\end{array}$ & $\begin{array}{c}\text { vào } \\
\text { rừng } \\
350 \mathrm{~m}\end{array}$ & $\begin{array}{c}\text { vào } \\
\text { rừng } \\
550 \mathrm{~m}\end{array}$ & $\begin{array}{c}\text { sau } \\
\text { rừng }\end{array}$ & $\begin{array}{c}\text { vào } \\
\text { rừng } \\
150 \mathrm{~m}\end{array}$ & $\begin{array}{c}\text { vào } \\
\text { rừng } \\
350 \mathrm{~m}\end{array}$ & $\begin{array}{c}\text { vào } \\
\text { rừng } \\
550 \mathrm{~m}\end{array}$ & $\begin{array}{c}\text { sau } \\
\text { rừng }\end{array}$ \\
\hline $13 \mathrm{~h} 00$ & 0,42 & 0,19 & 0,04 & 0,04 & 0,01 & 55 & 90 & 90 & 98 \\
\hline $13 \mathrm{~h} 15$ & 0,34 & 0,15 & 0,05 & 0,04 & 0,02 & 56 & 85 & 88 & 94 \\
\hline $13 \mathrm{~h} 30$ & 0,36 & 0,16 & 0,03 & 0,03 & 0,02 & 56 & 92 & 92 & 94 \\
\hline $13 \mathrm{~h} 45$ & 0,45 & 0,23 & 0,06 & 0,05 & 0,02 & 49 & 87 & 89 & 96 \\
\hline $14 \mathrm{~h} 00$ & 0,52 & 0,25 & 0,08 & 0,06 & 0,03 & 52 & 85 & 88 & 94 \\
\hline $14 \mathrm{~h} 15$ & 0,46 & 0,2 & 0,06 & 0,04 & 0,02 & 57 & 87 & 91 & 96 \\
\hline $14 \mathrm{~h} 30$ & 0,53 & 0,26 & 0,07 & 0,03 & 0,02 & 51 & 87 & 94 & 96 \\
\hline $14 \mathrm{~h} 45$ & 0,45 & 0,23 & 0,06 & 0,05 & 0,03 & 49 & 87 & 89 & 93 \\
\hline $15 \mathrm{~h} 00$ & 0,43 & 0,19 & 0,04 & 0,04 & 0,02 & 56 & 91 & 91 & 95 \\
\hline $15 \mathrm{~h} 15$ & 0,47 & 0,21 & 0,05 & 0,04 & 0,03 & 55 & 89 & 91 & 94 \\
\hline $15 \mathrm{~h} 30$ & 0,46 & 0,2 & 0,05 & 0,03 & 0,02 & 57 & 89 & 93 & 96 \\
\hline $15 \mathrm{~h} 45$ & 0,41 & 0,19 & 0,04 & 0,04 & 0,03 & 54 & 90 & 90 & 93 \\
\hline Trung & & & & & & & & & \\
\hline bình & 0,44 & 0,21 & 0,05 & 0,04 & 0,02 & 54 & 88 & 91 & 95 \\
\hline
\end{tabular}

Kết quả đo độ cao và tính hệ số suy giảm độ cao sóng tại dải rừng có độ rộng $700 \mathrm{~m}$ (bao gồm $650 \mathrm{~m}$ dải rừng trồng, $50 \mathrm{~m}$ dải rừng tái sinh sát đê) vào ngày nước cường tháng 8 năm 2008 được thể hiện trên bảng 3 .

Khi mực nước đạt giá trị lớn nhất kết hợp với gió thổi vuông góc với dải rừng, độ cao sóng trung bình tại vùng nước phía trước rừng $(100 \mathrm{~m})$ là $0,44 \mathrm{~m}$. Khi vào sâu trong rừng $350 \mathrm{~m}$, độ cao sóng giảm xuống $0,05 \mathrm{~m}$, hệ số suy giảm là $88 \%$. Vượt qua dải rừng có độ rộng $700 \mathrm{~m}$ vào sát chân đê, độ cao sóng giảm xuống chỉ còn $0,02 \mathrm{~m}$.

Kết quả đo độ cao và tính hệ số suy giảm độ cao sóng tại dải rừng tại xã Bàng La vào ngày nước cường tháng 8 năm 2011 được thể hiện trên bảng 4 . 
Bảng 4: Độ cao và hệ số suy giảm độ cao sóng tại bãi có dải rừng rộng 900m tại Bàng La - sóng hướng Đông Nam (11/08/2011)

\begin{tabular}{|c|c|c|c|c|c|c|c|c|c|}
\hline \multirow{2}{*}{$\begin{array}{c}\text { Thời } \\
\text { gian }\end{array}$} & \multicolumn{4}{|c|}{ Độ cao sóng $\mathbf{( m )}$} & \multicolumn{3}{c|}{ Hệ số suy giảm (\%) } \\
\cline { 2 - 11 } & $\begin{array}{c}\text { Trước } \\
\text { rừng }\end{array}$ & $\begin{array}{c}\text { vào } \\
\text { rừng } \\
150 \mathrm{~m}\end{array}$ & $\begin{array}{c}\text { vào } \\
\text { rừng } \\
350 \mathrm{~m}\end{array}$ & $\begin{array}{c}\text { vào } \\
\text { rừng } \\
550 \mathrm{~m}\end{array}$ & $\begin{array}{c}\text { sau } \\
\text { rừng }\end{array}$ & $\begin{array}{c}\text { vào } \\
\text { rừng } \\
150 \mathrm{~m}\end{array}$ & $\begin{array}{c}\text { vào } \\
\text { rừng } \\
350 \mathrm{~m}\end{array}$ & $\begin{array}{c}\text { vào } \\
\text { rừng } \\
550 \mathrm{~m}\end{array}$ & $\begin{array}{c}\text { sau } \\
\text { rừng }\end{array}$ \\
\hline $14 \mathrm{~h} 00$ & 0,49 & 0,24 & 0,08 & 0,05 & 0,02 & 51 & 84 & 90 & 96 \\
\hline $14 \mathrm{~h} 15$ & 0,46 & 0,2 & 0,06 & 0,04 & 0,01 & 57 & 87 & 91 & 98 \\
\hline $14 \mathrm{~h} 30$ & 0,47 & 0,2 & 0,05 & 0,05 & 0,02 & 57 & 89 & 89 & 96 \\
\hline $14 \mathrm{~h} 45$ & 0,48 & 0,22 & 0,06 & 0,04 & 0,01 & 54 & 88 & 92 & 98 \\
\hline $15 \mathrm{~h} 00$ & 0,51 & 0,23 & 0,06 & 0,05 & 0,02 & 55 & 88 & 90 & 96 \\
\hline $15 \mathrm{~h} 15$ & 0,52 & 0,25 & 0,08 & 0,04 & 0,02 & 52 & 85 & 92 & 96 \\
\hline $15 \mathrm{~h} 30$ & 0,51 & 0,22 & 0,06 & 0,05 & 0,02 & 57 & 88 & 90 & 96 \\
\hline $15 \mathrm{~h} 45$ & 0,53 & 0,26 & 0,07 & 0,06 & 0,03 & 51 & 87 & 89 & 94 \\
\hline $16 \mathrm{~h} 00$ & 0,52 & 0,25 & 0,08 & 0,06 & 0,03 & 52 & 85 & 88 & 94 \\
\hline $16 \mathrm{~h} 15$ & 0,52 & 0,23 & 0,07 & 0,05 & 0,01 & 56 & 87 & 90 & 98 \\
\hline $16 \mathrm{~h} 30$ & 0,51 & 0,22 & 0,06 & 0,05 & 0,01 & 57 & 88 & 90 & 98 \\
\hline $16 \mathrm{~h} 45$ & 0,49 & 0,21 & 0,04 & 0,03 & 0,01 & 57 & 92 & 94 & 98 \\
\hline $17 \mathrm{~h} 00$ & 0,47 & 0,2 & 0,04 & 0,03 & 0,01 & 57 & 91 & 94 & 98 \\
\hline Trung & & & & & & & & & \\
bình & 0,50 & 0,23 & 0,06 & 0,05 & 0,02 & 55 & 88 & 91 & 97 \\
\hline
\end{tabular}

Khi mực nước đạt giá trị lớn nhất, độ cao sóng trung bình tại vùng nước phía trước rừng $(100 \mathrm{~m})$ là $0,50 \mathrm{~m}$. Khi vào sâu trong rừng $350 \mathrm{~m}$, độ cao sóng chỉ còn $0,06 \mathrm{~m}$, hệ số suy giảm là $88 \%$. Vượt qua dải rừng có độ rộng $900 \mathrm{~m}$, độ cao sóng giảm xuống chỉ còn $0,02 \mathrm{~m}$. Như vậy, hệ số suy giảm độ cao sóng sau dải rừng $900 \mathrm{~m}$ (trong đó có $200 \mathrm{~m}$ dải rừng bần chua rìa ngoài có độ tuổi 1,5 ; cây còn nhỏ, khả năng cản sóng không đáng kể; $50 \mathrm{~m}$ dài rừng trang tái sinh sát chân đê có khả năng cản sóng tương đối tốt do mật độ dày) đạt $97 \%$.

\section{Tác động của rừng ngập mặn đến quá trình bồi lắng}

Tại những nơi có RNM, ví dụ như tại xã Bàng La, quận Đồ Sơn và xã Đại Hợp, huyện Kiến Thụy do ảnh hưởng tích cực của các dải RNM nên vùng biển này hiện đang diễn ra quá trình bồi tụ. Theo kết quả phân tích tại phòng thí nghiệm Địa môi trường, Viện Tài nguyên và Môi trường biển Việt Nam (2010), lớp trầm tích bồi lắng ở tầng mặt và ở độ sâu $40 \mathrm{~cm}$ dưới nền đáy đã được nghiên cứu và cho thấy phần đất bồi lắng ở khu vực này chủ yếu là bùn sét và bùn sét bột (bảng 5). 
Bảng 5: Đặc điểm trầm tích tại khu vực nghiên cứu

\begin{tabular}{|c|c|c|c|c|c|}
\hline \multirow[b]{2}{*}{ STT } & \multirow[b]{2}{*}{ Ký hiệu mẫu } & \multicolumn{3}{|c|}{ Thông số trầm tích } & \multirow{2}{*}{$\begin{array}{c}\text { Loại } \\
\text { trầm tích }\end{array}$} \\
\hline & & $\begin{array}{c}\mathbf{M}_{\mathbf{d}} \\
(\mathbf{m m})\end{array}$ & $\mathbf{S}_{\mathrm{o}}$ & $\mathbf{S}_{\mathrm{k}}$ & \\
\hline 1 & $\begin{array}{l}\text { Bàng La - Đồ Sơn và } \\
\text { Đại Hợp - Kiến Thụy } \\
\text { (bề mặt nền đáy rừng) }\end{array}$ & 0,004 & 2,131 & 1,119 & Bùn sét \\
\hline 2 & $\begin{array}{c}\text { Bàng La - Đồ Sơn và } \\
\text { Đại Hợp - Kiến Thụy } \\
\text { (độ sâu 40cm dưới nền đáy } \\
\text { rừng) }\end{array}$ & 0,007 & 2,941 & 1,243 & Bùn sét bột \\
\hline
\end{tabular}

Như vậy, những nơi có RNM thì chính chúng là yếu tố tạo đất tích cực mở rộng vùng sình lầy ven biển, nâng độ cao nền đáy.

Qua bảng 6 dưới đây cho thấy, tốc độ bồi tụ trung bình ở những khu vực có RNM xã Bàng La - Đồ Sơn, Đại Hợp - Kiến Thụy biến đổi trong khoảng 3,3 - 4,7cm/năm vào mùa mưa và $1,8-2,2 \mathrm{~cm}$ vào mùa khô.

Bảng 6: Tốc độ bồi lắng tại khu vực Bàng La (Đơn vị tính: $\mathrm{cm}$ )

\begin{tabular}{|c|c|c|c|}
\hline Năm & Mùa mưa & Mùa khô & Cả năm \\
\hline 2004 & 3,3 & 1,8 & 5,1 \\
\hline 2005 & 3,4 & 1,9 & 5,3 \\
\hline 2006 & 3,6 & 1,9 & 5,5 \\
\hline 2008 & 3,9 & 2,1 & 6,0 \\
\hline 2009 & 4,3 & 2,1 & 6,4 \\
\hline 2010 & 4,5 & 2,2 & 6,7 \\
\hline 2011 & 4,7 & 2,2 & 6,9 \\
\hline 2012 & & 2,1 & \\
\hline
\end{tabular}

Qua số liệu trên ta thấy, năm 2004, RNM có độ tuổi thấp (5 - 6 tuổi) nên khả năng cản sóng chưa cao, độ bồi tụ nền đáy cả năm ở mức $5,1 \mathrm{~cm}$. 
Đến năm 2006, rừng cây ngập mặn đã phát triển lớn hơn về kích cỡ như chiều cao, chiều rộng thân cây (bảng 1), do đó hiệu quả cản sóng tăng lên. Điều đó đồng nghĩa với việc phù sa được giữ lại nhiều hơn và mức độ bồi tụ tăng dần (bảng 6).

Đến năm 2008, cùng với sự sinh trưởng và phát triển của RNM, mức độ bồi tụ cũng tăng dần: từ $5,5 \mathrm{~cm} /$ năm vào 2006 , đạt tới $6,0 \mathrm{~cm} /$ năm vào năm 2008 . Cây tái sinh đến giai đoạn này đã bắt đầu xuất hiện nhiều ở phía chân đê, tốc độ sinh trưởng rất nhanh (bảng 1).

Đến năm 2010, rừng trồng vẫn tiếp tục sinh trưởng, phát triển tốt và rừng tái sinh phía sát chân đê phát triển mạnh làm cho bức tường cản sóng, gió ngày càng kiên cố hơn.

Quá trình bồi tụ cũng tác động tích cực trở lại đối với cây ngập mặn. Các kết quả khảo sát của tác giả trong thời gian nghiên cứu ở khu vực này cho thấy cây ngập mặn phát triển tốt và bồi tụ làm tăng độ cao nền đáy theo từng năm về phía đất liền và ra phía biển. Hiện nay, khu vực được bồi tụ nhanh hơn nằm trong khoảng dải rừng $200-400 \mathrm{~m}$ từ rìa phía biển trở vào (hình 4). Trung bình, từ năm 2004 đến 2012, các gốc cây bần trồng bị vùi sâu xuống $41,9 \mathrm{~cm}$, có chỗ tới $48,8 \mathrm{~cm}$ do quá trình bồi tụ.

\section{KẾT LUẬN}

Từ năm 1999 đến nay, dải RNM tại xã Bàng La (Đồ Sơn, Hải Phòng) do được trồng đúng quy cách nên đã sinh trưởng và phát triển tốt. Qua khảo sát và nghiên cứu, có thể đưa ra một số kết luận như sau:

- Tốc độ bồi lắng ở khu vực nghiên cứu phụ thuộc chặt chẽ vào độ tuổi và kiểu cấu trúc của RNM.

- Khi rừng trang, trang xen bần tăng thêm 1 tuổi, thì tốc độ bồi tụ trung bình của nền đáy sẽ tăng lên khoảng $0,3 \mathrm{~cm} /$ năm. Khi tuổi rừng càng cao (trong giới hạn còn phát triển), tốc độ bồi tụ càng nhiều hơn ở những năm sau.

- RNM và quá trình bồi tụ có mối quan hệ tương hỗ lẫn nhau. RNM càng phát triển, thì khả năng chắn sóng, gió tác động vào bờ càng cao và độ bồi tụ càng tăng.

\section{TÀI LIỆU THAM KHẢO}

1. Aksornkoae, S. 1993. Ecology and management of mangroves. The IUCN wetlands programme. IUCN: 137.

2. Bộ tư lệnh Hải quân (2004, 2005, 2006, 2007, 2008, 2009, 2010, 2011, 2012). Bảng thuỷ triều. Tập 1, NXB Quân đội nhân dân. 
3. Braun - Blanquet, J. 1932. Plant Sociology: the study of plant communities. Mc Graw - Hill, New York.

4. Phan Nguyên Hồng, Hoàng Thị Sản, 1993. Mangroves of Vietnam. IUCN Bangkok, 173p.

5. Mazda, Y. ; Wolanski, E.; King, B. ; Save, A.; Ohstuka, D.; Magi M., 1997. Drag force due to vegetation in mangrove swamps. Mangrove and Salt Marshes, vol. 1, pp.193-199.

6. Vũ Đoàn Thái (2005). Bước đầu nghiên cứu một số kiểu cấu trúc RNM ven biển Hải Phòng ảnh hưởng đến khả năng chắn sóng bảo vệ bờ biển. Tạp chí Khoa học. Số 1, 2005, ĐHSP Hà Nội.

7. Trần Đức Thạnh, Trần Đình Lân, Phạm Văn Lượng, Đinh Văn Huy, 2001. Ảnh hưởng của hoạt động nhân tác đối với môi trường ven biển trong mối quan hệ tương tác lục địa - biển. Tuyển tập tài nguyên và môi trường biển, tập VIII. NXB KH\&KT, Hà Nội.

8. Tiêu chuẩn ngành, 1991. Qui phạm quan trắc hải văn ven bờ, 94TCN 8-91. Xí nghiệp in Khí tượng Thuỷ văn phát hành.

\section{ROLE OF MANGROVES ON COASTAL DEPOSITION IN BANG LA (DO SON, HAI PHONG)}

\section{VU DOAN THAI}

Results of research on mangrove forest shown the process of alluvial deposition is always combined with growing up of mangrove forest. In this paper, the author show the results on the role of planted mangrove forest for the decreasing wave high, and strengthening alluvial deposition in Bang La coastal area (Do Son District, Haiphong City). This role has been increased with the age of mangrove during studied period.

Ngày nhận bài: 01 - 3 - 2012

Người nhận xét: PGS. TS. Trần Đức Thạnh 